\title{
Anaerobes in men with urethritis
}

\author{
E A FONTAINE, D TAYLOR-ROBINSON, N F HANNA, AND E D COUFALIK \\ From the Sexually Transmitted Diseases Research Group, Division of Communicable Diseases, Clinical \\ Research Centre, Harrow, Middlesex
}

SUMMARY Sixty-four men with non-gonococcal urethritis (NGU), seven with gonococcal urethritis (GU), and 30 who had no symptoms or signs of urethritis were studied. Chlamydia trachomatis was isolated from urethral specimens taken from $22 \%$ of the men with NGU, and $18 \%$ with GU, but not from those who did not have urethritis even though $20(67 \%)$ of them had a history of NGU, GU, or both. The chlamydial isolation rate for men having NGU for the first time was $30 \%$. Ureaplasma urealyticum was isolated from $42 \%$ of the men with NGU, $43 \%$ of men with GU, and $27 \%$ of those without urethritis.

In addition to aerobes anaerobes were isolated frequently from men whether or not they had urethritis, the most common being anaerobic Corynebacteria, peptococci, and micro-organisms of the Bacteroides-Fusobacteria group. There was no appreciable difference in the overall isolation of anaerobes from men with NGU $(\mathbf{8 9 \%})$ or from those without disease $(80 \%)$. The rate of isolation of a Gram-negative anaerobic bacillus from men with NGU (50\%) was, however, strikingly different to that from men with GU (14\%) or from those without disease $(13 \%)$. Furthermore, this bacillus was recovered from $28(56 \%)$ of 50 men with NGU who were considered chlamydia-negative and from $19(61 \%)$ of 31 men who were both chlamydia-negative and ureaplasma-negative. The effect of antibiotic treatment was evaluated in a few patients only, so that although those from whom the Gram-negative bacillus was eliminated by tetracycline recovered clinically there is a need for a prospective therapeutic trial to evaluate further the importance of the bacillus.

\section{Introduction}

It is now established that Chlamydia trachomatis organisms cause non-gonococcal urethritis (NGU), ${ }^{1}$ and the evidence that Ureaplasma urealyticum organisms cause some cases of the disease is persuasive. $^{2}$ The aetiology is, however, unexplained in perhaps half of the patients. Nevertheless, a significant number of patients from whom neither chlamydiae nor ureaplasmas can be isolated respond to treatment with tetracyclines. ${ }^{34}$ This suggests that another tetracycline-sensitive micro-organism(s) or agent(s) might be responsible for some cases of NGU. While various bacteria-namely, Staphylococcus epidermidis, ${ }^{5}$ Corynebacteria species, ${ }^{7-9}$ and Clostridium difficile ${ }^{10}$-have been associated with the disease evidence that they are a cause has not been confirmed. No other anaerobes have been implicated in NGU. ${ }^{11-13}$ Since the anterior

Address for reprints: Dr D Taylor-Robinson, Division of Communicable Diseases, Clinical Research Centre, Watford Road, Harrow, Middlesex HAi 3UJ

Accepted for publication 20 April 1982 urethra is colonised by a great variety of anaerobic species, as well as aerobic bacteria, we considered it possible that the role of one of these might have been overlooked. Furthermore, anaerobic infections of the human urinary tract are well documented..$^{14}$ In view of this, we have re-examined the possible role of anaerobes in NGU and present data which suggest that one group of these organisms may be important.

\section{Patients and methods}

CRITERIA FOR INCLUSION IN THE STUDY

Approval for the study was obtained from an ethics committee.

\section{Nongonococcal urethritis (NGU)}

Thirty-six male patients who attended one venereal diseases clinic and 28 male patients attending another were studied. They were sexually active men between 17 and 42 years old (mean 26 years) complaining of dysuria or urethral discharge or both. Although selection was at random to include patients who had NGU and post-gonococcal urethritis (PGU), particular emphasis was placed on including those 
who had no history of NGU before their first attendance. In addition, the following criteria had to be met: (a) absence of intracellular Gram-negative diplococci in a smear of the urethral exudate and the failure to culture Neisseria gonorrhoeae; (b) the presence of 10 or more polymorphonuclear (PMN) leucocytes/high power field (average of five fields) in a smear of urethral exudate; (c) antibiotics had not been taken for a least one month before attendance; (d) urine had not been voided for at least three hours before examination; (e) the patients were willing to be examined again seven days after treatment had begun; and (f) the patients were willing to refrain from sexual contact during the course of the study.

\section{Gonococcal urethritis}

Seven patients were examined whose urethral exudates contained Gram-negative diplococci and who had positive culture results for $N$ gonorrhoeae. In addition, these patients fulfilled the criteria (b) to (f) outlined above.

\section{Without urethritis}

Thirty men who fulfilled the criteria but had no symptoms or signs of gonorrhoea or NGU were selected for study. Nineteen of these men had a history of NGU.

\section{FIRST VISIT}

After a preliminary diagnosis had been made on the basis of a urethral smear, patients were sampled by inserting consecutively three calcium alginate nasopharyngeal swabs (Medical Wire and Equipment Co Ltd), premoistened in a basal medium containing $5 \%$ bovine serum, into the urethra $2-3 \mathrm{~cm}$ beyond the fossa navicularis. The first swab was used for the isolation of $C$ trachomatis, $U$ urealyticum, and Mycoplasma hominis, and the second and third for the isolation of anaerobes, one being inoculated on prereduced agar medium in the clinic and the other being placed in liquid transport medium.

The first $20 \mathrm{ml}$ of voided urine was collected from 12 patients before and after swabbing, and the surface of the urine was layered with sterile paraffin oil.

Patients with NGU or PGU were treated with $300 \mathrm{mg}$ triple tetracycline ${ }^{16}$ or $250 \mathrm{mg}$ oxytetracycline twice daily for seven days. Patients who had gonorrhoea were given $480 \mathrm{mg}$ co-trimoxazole twice daily for seven days. If there was only partial or no improvement in symptoms and signs, the patient's antibiotic regimen was altered to triple tetracycline and metronidazole $200 \mathrm{mg}$ each or erythromycin $250 \mathrm{mg}$ three times daily for seven days.
FOLLOW-UP VISIT

Patients who returned seven days after the first visit to the clinic were examined and questioned about the nature of any residual symptoms, and swabs were obtained as described.

\section{MICROBIOLOGICAL METHODS Gonococci}

$N$ gonorrhoeae was isolated on GC agar base supplemented with $1 \%$ Isovitalex and $2 \%$ haemoglobin, क and cultures were incubated at $37^{\circ} \mathrm{C}$ in an $\vec{\circ}$ atmosphere of $5 \%$ carbon dioxide in air for 24 hours.

\section{Chlamydiae and mycoplasmas}

A urethral swab was agitated and expressed in $2 \mathrm{ml}$ sucrose-phosphate transport medium containing $10 \%$ fetal calf serum (2SP) but without antibiotics. The swab was discarded and the specimen stored immediately in liquid nitrogen until cultured for $C$ trachomatis, $U$ urealyticum, and $M$ hominis. ${ }^{17}$

\section{Anaerobic bacteria}

A urethral swab was inoculated directly on blood agar in the clinic. The medium consisted of $3 \%$ tryptone soya broth base supplemented with $0.5 \%$ yeast extract, $0.3 \%$ Lab-Lemco powder, $0.3 \%$ neutralised peptone, $0 \cdot 1 \%$ Tween-80, and 3\% agar reduced with $0.1 \%$ cysteine hydrochloride and $0.02 \%$ pure iron filings suspended in phosphatebuffered saline. Before use, haemin $(5 \mu \mathrm{g} / \mathrm{ml})$, menadione $(2 \mu \mathrm{g} / \mathrm{ml})$, and $5-10 \%$ defibrinated sheep blood were added. Another urethral swab was immersed immediately in $2 \mathrm{ml}$ of a liquid transport medium, the wire shaft of the swab being cut and discarded. The medium consisted of $0.5 \%$ tryptone, $0.5 \%$ yeast extract, $0.1 \%$ glucose, $3 \%$ bovine serum, and $0.1 \%$ cysteine hydrochloride. The redox potential was reduced further by adding $10 \mathrm{ml}$ of a titanium trichloride-citrate complex, prepared as described, ${ }^{18}$ to $100 \mathrm{ml}$ of the medium. The agar plates, liquid transport medium, and urine specimens were transported in a Gas-Pak jar to the laboratory, where they were taken inside an anaerobic cabinet. The swabs were agitated and expressed in the transport medium, which was then diluted fivefold in fresh medium and plated on agar medium. The urine specimens were removed from the cabinet, centrifuged at $600 \times g$ for 15 minutes and returned to the cabinet where the deposits were diluted and plated as described. All the cultures were incubated at $37^{\circ} \mathrm{C}$ inside the anaerobic cabinet for $7-8$ days.

IDENTIFICATION OF MICRO-ORGANISMS

Organisms producing a colour change in ureacontaining medium were regarded presumptively as $U$ urealyticum and those which hydrolysed arginine $\vec{\Rightarrow}$ 
as $M$ hominis. Anaerobes were identified by using Gram-stain, selective media, and the multitest fermentation microsystem (Minitek). Aerobic bacteria were identified by standard biochemical procedures and gonococci by Gram-staining and a positive reaction in the oxidase test.

\section{Results}

\section{COMPARISON OF SAMPLING TECHNIQUES FOR ANAEROBES}

Specimens were taken from 12 patients with NGU by three sampling methods initially; the results of testing them for anaerobes are shown in table I. A urethral swab transported in liquid transport medium, which was then processed in an anaerobic cabinet, provided the largest number of morphotypes. The number recovered increased as the oxidation-reduction potential $\left(E_{h}\right)$ of the transport medium decreased. This procedure was used, therefore, for the quantitative isolation of anaerobes from all the other men studied subsequently.

\section{ISOLATION OF ANAEROBES}

Sixty-four men with NGU, seven with gonorrhoea, and 30 without clinical symptoms or signs were studied. Anaerobes were isolated from the urethra of $57(89 \%)$ of the patients with NGU, all $(100 \%)$ of those with gonorrhoea, and from $24(80 \%)$ of the men without disease at the time they were sampled.

The anaerobes could be ascribed to five groups, and these and the distribution of species are shown in table II. Anaerobes comprising all the groups were found in patients with and without disease.

TABLE I Recovery of anaerobic morphotypes from 12 patients with NGU by three sampling methods

\begin{tabular}{|c|c|c|c|c|c|}
\hline \multirow[b]{3}{*}{ No of anaerobic morphotypes } & \multicolumn{4}{|c|}{ No of patients from whom indicated No of morphotypes isolated by: } & \multirow{3}{*}{$\begin{array}{l}\text { Redox potential of liquid } \\
\text { transport medium } \\
\left(E_{h} \text { at } p H 7 \cdot 0\right)\end{array}$} \\
\hline & \multicolumn{2}{|c|}{ Testing urine } & \multirow{2}{*}{$\begin{array}{l}\text { Direct } \\
\text { agar } \\
\text { culture* }\end{array}$} & \multirow{2}{*}{$\begin{array}{l}\text { Testing } \\
\text { liquid } \\
\text { transport } \\
\text { medium }\end{array}$} & \\
\hline & $\begin{array}{l}\text { Before } \\
\text { swabbing }\end{array}$ & $\begin{array}{l}\text { After } \\
\text { swabbing }\end{array}$ & & & \\
\hline $\begin{array}{l}0 \\
1 \\
2 \\
3 \\
4 \\
5 \\
6\end{array}$ & $\begin{array}{l}9 \\
3 \\
0 \\
0 \\
0 \\
0 \\
0\end{array}$ & $\begin{array}{l}0 \\
1 \\
8 \\
2 \\
1 \\
0 \\
0\end{array}$ & $\begin{array}{l}0 \\
2 \\
9 \\
1 \\
0 \\
0 \\
0\end{array}$ & $\begin{array}{l}0 \\
0 \\
3 \\
3 \\
3 \\
1 \\
2\end{array}$ & $\begin{array}{l}\text { NT } \\
\text { NT } \\
-150 \mathrm{mV} \\
-160 \mathrm{mV} \\
-170 \mathrm{mV} \\
-175 \mathrm{mV} \\
-275 \text { to } 300 \mathrm{mV}\end{array}$ \\
\hline
\end{tabular}

${ }^{*} \mathrm{E}_{\mathrm{h}}=-100$ to $-150 \mathrm{mV} ; \mathrm{NT}=$ not tested

TABLE II Groups and species of anaerobes isolated from the urethra of 101 men with and without urethritis

\begin{tabular}{|c|c|c|c|c|c|}
\hline \multirow{2}{*}{\multicolumn{2}{|c|}{ Anaerobe }} & \multicolumn{3}{|c|}{ No $(\%)$ of patients with the indicated anaerobes: } & \multirow{3}{*}{$\begin{array}{l}\text { Viable } \mathrm{No} / \mathrm{ml} \\
\text { in NGU }\end{array}$} \\
\hline & & \multirow{2}{*}{$\begin{array}{l}\text { Non-gonococcal } \\
\text { urethritis }(n=64)\end{array}$} & \multirow{2}{*}{$\begin{array}{l}\text { Gonococcal } \\
\text { urethritis }(n=7)\end{array}$} & \multirow{2}{*}{$\begin{array}{l}\text { No urethritis } \\
(n=30)\end{array}$} & \\
\hline Group & Species & & & & \\
\hline 1 & $\begin{array}{l}\text { Gram-negative bacilli: } \\
\text { Bacteroides } \mathrm{sp} \\
\text { B melaninogenicus } \\
\text { Fusobacterium } \mathrm{sp}\end{array}$ & $29(45)$ & $5(71)$ & $8(27)$ & $<1 \times 10^{5}$ \\
\hline 2 & "Symbiotic" bacillus & $32(50)$ & $1(14)$ & $4(13)$ & $>2 \times 10^{6}$ \\
\hline 3 & $\begin{array}{l}\text { Gram-positive non- } \\
\text { sporing bacilli: } \\
\text { Corynebacteria spp } \\
\text { Bifidobacterium sp } \\
\text { Propionibacterium acnes } \\
\text { Eubacterium sp }\end{array}$ & $35(55)$ & $5(71)$ & $8(27)$ & $<8 \times 10^{5}$ \\
\hline 4 & $\begin{array}{l}\text { Gram-positive sporing } \\
\text { bacilli: } \\
\text { Clostridium spp } \\
C \text { sporogenes } \\
C \text { bifermentans }\end{array}$ & $8(13)$ & $1(14)$ & $5(17)$ & $<1 \times 10^{5}$ \\
\hline 5 & $\begin{array}{l}\text { Gram-positive cocci: } \\
\text { Peptococcus } \mathrm{spp} \\
\text { Gaffkya anaerobia } \\
\text { Pc asaccharolyticus } \\
\text { Pc constellatus } \\
\text { Pc productus }\end{array}$ & $48(75)$ & $6(85)$ & $20(67)$ & $>2 \times 10^{6}$ \\
\hline 6 & No anaerobes & $7(10)$ & $0(0)$ & $6(20)$ & \\
\hline
\end{tabular}


Peptococcus spp were isolated most frequently while Clostridium spp were isolated least frequently, and both were distributed almost equally among patients with and without disease. On the other hand, anaerobic coryneforms and Gram-negative bacilli of the Bacteroides-Fusobacterium group occurred more frequently in patients with disease than in those without. The most striking difference in the occurrence of micro-organisms in the various patients, however, was seen in the case of a Gram-negative bacillus (group 2) which was isolated in large numbers from half the men with NGU but from only a small proportion of men with gonococcal urethritis or those without disease. This bacillus appeared to be symbiotic, invariably growing synergistically with Gaffkya anaerobia as well as with other species of the facultative anaerobes, some of which were microaerophilic (table III).

\section{ISOLATION OF FACULTATIVE ANAEROBES}

The occurrence of facultative anaerobes in the various groups of patients is shown in table III. The Gram-positive cocci, which were predominantly staphylococci, were found frequently but about equally in all groups of patients. Gram-positive bacilli, mainly Corynebacteria spp, were also isolated frequently but least often from subjects without disease.

\section{ISOLATION OF CHLAMYDIAE AND \\ MYCOPLASMAS}

$C$ trachomatis was isolated from $14(22 \%)$ of the 64 patients with NGU, from two $(28 \%)$ of the seven patients with gonococcal urethritis, but not from 30 men who did not have urethritis. Twenty-three of the patients with NGU were having their first attack and $C$ trachomatis was isolated from seven $(30 \%)$ of them. $U$ urealyticum was isolated from $27(42 \%)$ patients with NGU, from three $\mathbf{( 4 3 \% )}$ ) patients with gonococcal urethritis, and from eight $(27 \%)$ without urethritis. $M$ hominis was found in eight $(13 \%)$

patients with NGU, in two $(28 \%)$ of those with gonococcal urethritis, and in six $(20 \%)$ without urethritis.

RELATIONSHIP OF ANAEROBES TO CHLAMYDIAPOSITIVE AND CHLAMYDIA-NEGATIVE NGU

This relationship is shown in table IV. Anaerobes were isolated from both chlamydia-positive and chlamydia-negative patients. In view of the illdefined aetiology of chlamydia-negative NGU, however, the occurrence of anaerobes in this group of patients was of particular interest. In the case of four of the five groups of anaerobes, there was little difference between their occurrence in chlamydiapositive or chlamydia-negative patients. The "symbiotic" Gram-negative bacillus, referred to previously (table II), however, was recovered from 38 $(56 \%)$ of 50 men with NGU who were regarded as chlamydia-negative but from only four $(28 \%)$ of 14 men who were chlamydia-positive. In addition, the bacillus was isolated from $19(61 \%)$ of 31 men who had negative results for both chlamydiae and ureaplasmas. This anaerobe was found also in $75 \%$ of men who were chlamydia-negative and having NGU for the first time.

TABLE IV Proportion of chlamydia-positive and chlamydia-negative patients with NGU from whom anaerobes were isolated

\begin{tabular}{|c|c|c|c|c|}
\hline \multirow[b]{2}{*}{ Anaerobe } & \multicolumn{2}{|c|}{$\begin{array}{l}\text { Chlamydia-positive } \\
(n=14)\end{array}$} & \multicolumn{2}{|c|}{$\begin{array}{l}\text { Chlamydia-negative } \\
(n=50)\end{array}$} \\
\hline & No & $\%$ & No & $\%$ \\
\hline \multicolumn{5}{|l|}{ Bacteroides/Fuso- } \\
\hline Gram-negative & & & & \\
\hline "symbiotic" bacillus & 4 & 28 & 28 & 56 \\
\hline Corynebacteria spp & 10 & 71 & 31 & 62 \\
\hline Clostridia spp & 3 & 21 & 7 & 14 \\
\hline Peptococcus spp & 12 & 86 & 40 & 80 \\
\hline
\end{tabular}

TABLE III Facultative anaerobes isolated from the urethra of 101 men with and without urethritis

\begin{tabular}{|c|c|c|c|}
\hline \multirow[b]{2}{*}{ Micro-organism } & \multicolumn{2}{|c|}{ No $(\%)$ of patients with the indicated bacteria } & \multirow[b]{2}{*}{$\begin{array}{l}\text { No urethritis } \\
(n=30)\end{array}$} \\
\hline & $\begin{array}{l}\text { Non-gonococcal } \\
\text { urethritis }(n=64)\end{array}$ & $\begin{array}{l}\text { Gonococcal } \\
\text { urethritis }(n=7)\end{array}$ & \\
\hline $\begin{array}{l}\text { Gram-positive cocci: } \\
\text { Staphylococcus aureus* } \\
\text { Staph epidermidis } \\
\text { Micrococcus varianst } \\
\text { Micrococcus fermentans } †\end{array}$ & $60(93)$ & $6(86)$ & $25(83)$ \\
\hline $\begin{array}{l}\text { Gram-positive bacilli: } \\
\text { Corynebacterium renale } \\
\text { C. xerosis } \\
\text { Lactobacillus sp }\end{array}$ & $54(85)$ & $6(86)$ & $12(40)$ \\
\hline \multicolumn{4}{|c|}{$\begin{array}{l}\text { *Only very rare in cases of NGU } \\
\text { tSome strains required } 5-10 \% \text { carbon dioxide in air for initial growth (microaerophilic) but became facultative on further culture }\end{array}$} \\
\hline
\end{tabular}


CLINICAL AND MICROBIOLOGICAL RESPONSE TO TREATMENT

Only 14 of the 64 men with NGU who were treated returned for a follow-up assessment (table V). Ten of the 14 patients with NGU were initially chlamydianegative but three were positive for both chlamydiae and ureaplasmas. Before treatment anaerobes were isolated from all 14 men and the anaerobic Gramnegative bacillus was isolated from five $(71 \%)$ of seven men who had negative results for both chlamydiae and ureaplasmas and from four (57\%) of seven men who had positive results for either chlamydiae or ureaplasmas. The bacillus was also isolated, however, from two of the men who were treated and were initially chlamydia-negative and ureaplasma-positive. The response to treatment varied; four patients who harboured the Gramnegative bacillus initially did not respond microbiologically, cytologically, or symptomatically to triple tetracycline while two others, who apparently became infected with the bacillus after being free initially, showed a similar negative response. In contrast, the micro-organism disappeared from five patients who recovered completely after being given triple tetracycline. This must be balanced, however, against the fact that three patients from whom the Gram-negative bacillus was not isolated initially also responded completely to treatment. Interestingly, one of two asymptomatic subjects who was chlamydia-negative and from whom the Gramnegative bacillus was isolated developed NGU two weeks later.

\section{Discussion}

Although there have been numerous microbiological studies of NGU few workers ${ }^{12} 13$ have investigated the possible aetiological role of anaerobes in the disease. Hallén and his colleagues ${ }^{12}$ isolated anaerobes infrequently, and subjects without disease were not investigated. Bowie and his co-workers ${ }^{13}$ isolated more anaerobes from persons without disease $(\mathbf{9 1 \% )}$ than from those with NGU $(66 \%)$.

In the present study anaerobes were found in the urethra of men with and without urethritis and could be placed in five main groups. In general, our isolation of anaerobes and facultative anaerobes corresponded with the findings of some other groups of workers. ${ }^{12} 13$ Although we isolated $C$ sporogenes and $C$ bifermentans from a small number of patients with and without disease, we failed to isolate $C$ difficile from any of them. Overall anaerobic species were harboured more often by men with NGU $(90 \%)$ than by men without symptoms $(76 \%)$, but the Gramnegative bacillus was distinct from the others in that it was frequently isolated from patients with NGU

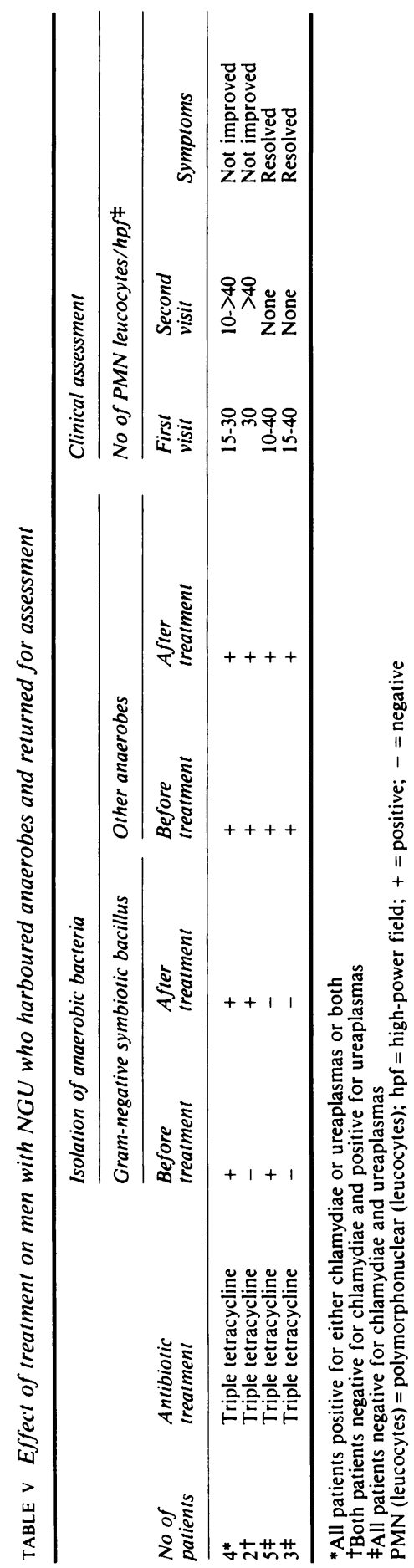


but rarely from those with gonococcal urethritis or from men regarded as asymptomatic. Although we used the same techniques as previously, ${ }^{31719}$ the recovery rate for chlamydiae was low and highest $(30 \%)$ in those men who had NGU for the first time. We cannot exclude the possibility that chlamydiae went undetected in a few patients and that the number of chlamydia-negative patients is falsely large. Ascribing a few of the chlamydia-negative patients to the chlamydia-positive group would probably not much affect the finding that the Gramnegative anaerobic bacillus occurred twice as frequently in chlamydia-negative men with NGU as in chlamydia-positive men. The difference is highlighted by the fact that a difference of this magnitude was not found for other anaerobes, these being isolated from $89 \%$ of chlamydia-negative patients, $76 \%$ of chlamydia-positive patients, and from the same proportion of men without urethritis.

The plethora of different species of anaerobes recovered from men with NGU is bewildering. We agree that most of these micro-organisms form part of the microflora of the urethra. ${ }^{1213}$ The small Gramnegative anaerobic non-sporing bacillus, however, needs further consideration. This is an unusual pigmented micro-organism which grows synergistically with Gaffkya anaerobia of the peptococcus group and other facultative Gram-positive cocci, some of which were microaerophilic on primary isolation. It is a fastidious, obligate anaerobe which appears to derive its energy from formate and fumarate or nitrate, used as electron donor and acceptor respectively (unpublished observations). Preliminary tests aimed at identification show that it reduces nitrate to nitrite, and is asaccharolytic, oxidasepositive, and resistant to vancomycin and cotrimoxazole. Its full identification and relationship to apparently similar micro-organisms isolated from the vagina by other workers require further study. ${ }^{20}$ Treatment of the patients was not designed to evaluate the importance of the micro-organisms, and although there was some correlation between the disappearance of the Gram-negative anaerobic bacillus and the clinical recovery of patients with NGU this aspect is not convincing. Furthermore, full assessment was marred by the poor follow-up attendance of patients. This may be attributable to some extent to the multiple swabbing procedure.

The most profitable line of further study would be to undertake a therapeutic trial of a tetracycline in comparison with this antibiotic combined with metronidazole, the antibiotic of choice for anaerobes. In such a trial, attention should be confined specifically to the Gram-negative anaerobic bacillus by using a selective medium. This approach would seem to be worthwhile because our evidence suggests that of all the anaerobes recoverable this is the one most likely to play a part in the aetiology of NGU.

We wish to thank Dr J R W Harris, for access to patients at the Praed Street Clinic, and to acknowledge the support of the staff of the special clinic at the Shrodells Wing of Watford General Hospital.

\section{References}

1. Taylor-Robinson D, Thomas BJ. The role of Chlamydia trachomatis in genital tract and associated diseases. J Clin Pathol 1980;33:203-33.

2. Taylor-Robinson D, Csonka GW. Laboratory and clinical aspects of mycoplasmal infections of the human genitourinary tract. In: Harris JRW, ed. Recent Advances in Sexually Transmitted Diseases. London: Churchill Livingstone 1981; 151-86.

3. Prentice MJ, Taylor-Robinson D, Csonka GW. Non-specific urethritis. A placebo controlled trial of minocycline in conjunction with laboratory investigations. $\mathrm{Br} J$ Vener Dis 1976;52:269-75.

4. Munday PE, Thomas BJ, et al. Clinical and microbiological study of non-gonococcal urethritis with particular reference to non-chlamydial disease. Br J Vener Dis 1981;57:327-33.

5. Hovelius B, Mårdh P-A, Thélin I. Staphylococcus saprophyticus in men with urethritis. In: Proceedings of the second meeting on Sexually Transmitted Diseases, Helsinki, Finland, August 9-10 1979. Abstract.

6. Malone $\mathrm{BH}$, Schreiber $\mathrm{M}$, et al. Obligatory anaerobic strains of Corynebacteria vaginale. J Clin Microbiol 1975;2:272-5.

7. Furness $\mathrm{G}$, Kamat $\mathrm{H}$, et al. Isolation of corynebacteria from non-specific urethritis. J Urol 1971;106:557-61.

8. Furness $\mathrm{G}$, Kamat $\mathrm{H}$, et al. An investigation of the relationship of non-specific urethritis corynebacteria to the other microorganisms found in the urogenital tract by means of a modified chocolate agar medium. Invest Urol 1973;10:378-91.

9. Furness G, Evangelista A, Kaminski Z. Biologic reactions differentiating commensals of the urogenital tract from the pathogens responsible for urethritis. Invest Urol 1977;15:23-7.

10. Hafiz S, McEntegart MG, et al. Clostridium difficile in the urogenital tract of males and females. Lancet 1975;i:420-1.

11. Justesen $T$, Nielsen $\mathbf{M}$, Hattel $T$. Anaerobic infections in chronic prostatitis and chronic urethritis. Med Microbiol Immunol 1973;158:237-48.

12. Hallén A, Ryden A-C, et al. The possible role of anaerobic bacteria in the aetiology of non-gonococcal urethritis in men. Br J Vener Dis 1977;53:368-71.

13. Bowie WR, Pollock HM, et al. Bacteriology of the urethra in normal men and men with nongonococcal urethritis. $J$ Clin Microbiol 1977;6:482-8.

14. Finegold SM, Miller LG, et al. Significance of anaerobic and capnophilic bacteria isolated from the urinary tract. In: Kass EH, ed. Progress in Pyelonephritis. Philadelphia: Davis and Co, 1965;159-78.

15. Segura $\mathrm{J}$, Kelalis $\mathrm{P}$, et al. Anaerobic bacteria in the urinary tract. Mayo Clin Proc 1972;47:30-3.

16. Willcox RR. Triple tetracycline in the treatment of nongonococcal urethritis in males. Br J Vener Dis 1972;48:137-40. S

17. Taylor-Robinson D, Evans RT, et al. Ureaplasma urealyticum and Mycoplasma hominis in chlamydial and non-chlamydial non-gonococcal urethritis. Br J Vener Dis 1979;55:30-5.

18. Fontaine EA, Taylor-Robinson D. Evaluation of liquid transport media for the isolation of anaerobic bacteria: relevance to genital tract specimens. J Infection 1981;3:360-9.

19. Coufalik ED, Taylor-Robinson D, Csonka GW. Treatment of non-gonococcal urethritis with rifampicin as a means of defining the role of Ureaplasma urealyticum. Br J Vener Dis 1979;55:36-43.

20. Fontaine EA, Taylor-Robinson D, et al. Anaerobic bacteria in lower genital tract infections. Lancet 1982;i:281. 